\title{
Effect of milk fat content on absorption of calcium carbonate and calcium phosphate mixture in Sprague Dawley rats
}

\author{
${ }^{1,2 *}$ Hardoko, ${ }^{2}$ Jasmine. V., ${ }^{2}$ Eveline, ${ }^{2,}{ }^{*}$ Halim, Y. and ${ }^{3}$ Antono, L. \\ ${ }^{1}$ Faculty of Fisheries and Marine Sciences, Universitas Brawijaya. Jl. Veteran No. 1 Malang 65113, \\ Indonesia \\ ${ }^{2}$ Food Technology Department, UPH, Jl. MH. Thamrin Boulevard No. 10010, Lippo Karawaci, Tangerang \\ 15811, Indonesia \\ ${ }^{3}$ PT. Nutrifood Indonesia, Kawasan Industri Pulogadung Jl. Rawabali II No.3. Jakarta 13920, Indonesia
}

\section{Article history:}

Received: 29 September 2019

Received in revised form: 24

November 2019

Accepted: 26 November 2019

Available Online: 23

December 2019

\section{Keywords:}

Absorption,

Calcium,

Fat,

Milk

DOI:

https://doi.org/10.26656/fr.2017.4(3).322

\begin{abstract}
Calcium absorption of standard milk is influenced by types of fat, other than types of calcium salts, vitamin D, PTH hormone, etc. However, calcium absorption on different fat content, particularly on milk, has not been reported. The purpose of this study was to determine the effect of the fat content of milk on the absorption of calcium carbonate and calcium phosphate mixture in rats. Experiments were conducted using 24 male Sprague Dawley rats fed with low-fat milk ( $0.5 \%$ fat), high-fat milk ( $26 \%$ fat), standard milk ( $8 \%$ fat) and without milk for three weeks. Amount of feed consumed, feces and urine samples were collected to determine the amount of absorbed calcium for five days in the third week. Calcium content in the samples was analyzed using AAS (Atomic Absorption Spectrophotometry). The results showed that there were no difference in calcium carbonate and calcium phosphate absorption among rats fed with low-fat milk, high-fat milk and standard milk. The calcium absorption level from milk reached an average of around $98.67 \pm 0.22 \%$. The absorption level of calcium carbonate and calcium phosphate mixture from milk was higher than control rats that were not fed with any milk. Fat content in milk did not affect the absorption of calcium carbonate and calcium phosphate mixture, but the milk consumption could increase the calcium absorption, compared to control.
\end{abstract}

\section{Introduction}

Milk is a nutritious beverage that is required by human during their growth period (Miller et al., 2007; Brown, 2011). The nutrient content of milk is higher compared to other food products, particularly its calcium content (Spungen, 2005; Hayes and Rachel, 2009; Hardinsyah and Wirna, 2010; Utama, 2011). High calcium content in milk made this product is recommended as a beverage to fulfill the requirement of calcium in the human body (Shinya, 2001).

Calcium required by the body is non-bonded calcium, soluble and in its ionic form so that it can be absorbed by the body (Allen, 1984). Calcium absorption inside the body is also influenced by the presence of Vitamin D and iron (Masri, 2011), synergistic action of vitamin $\mathrm{D}_{3}$ and parathyroid hormone (PTH) (Hoenderop et al., 2005), the ratio between calcium and phosphorous (Ayed dan Thannoun, 2006), the form of calcium salts (Howard et al., 2013), nano calcium (Park et al., 2007),
$\mathrm{pH}$, protein, fat, the presence of oxalate or phytate (Muchtadi et al., 1993; Almatsier, 2004) and the presence of lactose in milk (Abrams et al., 2002).

One of the factors that can influence calcium absorption is the types of fat of the food products. On standard fat content, Kelly et al. (2003) reported that PUFA n-6 linoleic acid from plants could increase calcium absorption compared to PUFA n-3 from the animal. Moreover, Lutz and Scharrer (1991) showed that short-chain fatty acids could also increase calcium absorption, as well as medium-chain triglycerides (Agnew and Holdsworth, 1971). Therefore, calcium absorption can be increased with the presence of those types of fat. On the other hand, Jacobsen et al. (2005) showed that the presence of fat could increase the calcium content in feces (fecal fat extraction), which means there was a decrease in calcium absorption due to the presence of fat. Total of trans fat, saturated fat, monosaturated, polyunsaturated (Alomaim et al., 2019) and long-chain triglycerides (Agnew and Holdsworth, 
1971) could decrease calcium digestion. Gacs and Barltrop (1977) reported that stearic acid and hexanoic acid could decrease calcium absorption because of calcium-binding by undigested fat in the body. A similar finding was also reported by Bendsen et al. (2008), who stated that calcium content in feces increased with the increase of fat content in feces. According to Muchtadi et al. (1993), the presence of fat would decrease calcium absorption, associated with an increase in fat transit time in the digestive tract.

Correlation between fat and calcium can also apply vice versa, i.e. absorption of fat is influenced by calcium. Lorenzen et al. (2007) and Jacobsen et al. (2005) reported that increase of the amount of calcium consumed could reduce fat absorption, but if the calcium consumption is low, then it has less effect on fat absorption (Alomaim et al., 2019). In case of type-2diabetic rats, Umami et al. (2015) reported that rats fed with milk powder with optimum calcium and Vitamin D content and high-fat feed, there was no increase in blood serum HDL, which means there is no increase in fat absorption. However, the effect of high-fat feed on calcium absorption is still unknown.

Based on its fat content, milk can be categorized into low-fat milk ( $1 \%$ fat), high-fat milk ( $>14 \%$ fat) and standard milk (4-13\% fat) (Miller et al., 2007; Belitz et al., 2009). Moreover, milk is considered as a potential source of calcium for the body. Milk is also considered as the caseinate protein source. According to Jacobsen et al. (2005), protein can help calcium absorption. Therefore, research is required to study the effect of fat content in milk on calcium carbonate and calcium phosphate mixture absorption and to determine the best fat content in milk that contributes to the highest calcium absorption.

\section{Materials and methods}

\subsection{Materials and equipment}

The research about calcium carbonate and calcium phosphate mixture absorption from milk on male Sprague Dawley rats was conducted in Animal Testing Laboratorium PAU Food and Nutrition, Gadjah Mada University, Yogyakarta.

The main materials used were milk powder with various fat content, i.e. low fat $(0.5 \mathrm{~g}$ fat per $30 \mathrm{~g}$ serving size), standard milk ( $3 \mathrm{~g}$ fat per $30 \mathrm{~g}$ serving size) and high-fat milk (9 $\mathrm{g}$ fat per $30 \mathrm{~g}$ serving size), which were obtained from PT. Nutrifood Indonesia. Types of calcium used were the mixture of calcium carbonate and tricalcium phosphate (1:1). Type of fat used was milk fat (cream). The supporting materials were water for rats, standard feed for rats that were prepared at PAU Food and Nutrition Laboratorium, Gadjah Mada University, with composition mentioned in Table 1.

Table 1. Nutritional content of the standard feed

\begin{tabular}{lc}
\hline Parameter & Feed \\
\hline Moisture content (\%) & 12 \\
Ash content (\%) & 3.97 \\
Protein content (\%) & 13.8 \\
Fat content (\%) & 6.17 \\
Crude fiber content (\%) & 4.38 \\
Total calcium content $(\%)$ & 1.49 \\
\hline
\end{tabular}

The equipment used for research were 7 week old male Sprague-Dawley rats with bodyweight of $210.66 \pm 7.25 \mathrm{~g}, 24$ modified metabolic cage and probe. The equipment used for analyses were mortar and pestle, bowl, spatula, ashing dish, Mohr pipette, dropping pipette, serological pipette, volumetric flask (Iwaki Pyrex), measuring cylinder, reaction tubes (Schott Duran), Whatman no. 42 filter paper, oven (Memmert), dessicator (Schott Duran), furnace (Memmert), analytical balance (Mettler Toledo AB204-S), Kjeldah tubes (Buchi), yarn, Soxhlet (Schott Duran), boiling flask, rotary evaporator (Buchi R124), heater (Thermo Scientific) and Atomic Absorbance Spectrophotometric (AA-7000 Shimadzu).

\subsection{Research method}

This experiment has obtained Ethical Clearance No. 1141/III/LPPM-PM.10.05/11/2014. In this research, 4 treatments were used, i.e. administration of low fat $(0.5 \mathrm{~g}$ fat per $30 \mathrm{~g}$ serving size), standard milk ( $3 \mathrm{~g}$ fat per $30 \mathrm{~g}$ serving size), high-fat milk ( $9 \mathrm{~g}$ fat per $30 \mathrm{~g}$ serving size), and feed without milk on 7-week-old male Sprague Dawley rats with average body weight of $210.66 \pm 7.25 \mathrm{~g}$. This experiment used 6 replications (6 rats) for each treatment and was done for 5 days consecutively. All data were analysed using ANOVA with SPSS version 16.0 software.

In the beginning, rats were adapted for 1 week with standard feed with composition mentioned in Table 1. After the adaptation period, 24 rats were divided into four groups of treatment, i.e. a group of rats fed with low -fat milk, a group of rats fed with standard milk, a group of rats fed with high-fat milk, and a group of control rats which were fed only with standard feed. The amount of milk-fed was based on rats' daily calcium needs. Milk was given parenterally using probes at 8 AM with the amount mentioned in Table 2. During the experiment, rats were fed with standard feed and drink ad libitum, and the amount of feed and drink consumed each day was also calculated (Widodo and Edy, 2006; Nugraheni, 2012). This experiment was conducted for three weeks. At the end of week 3, the amount of feed consumed, feces and urine samples were taken from all rats for 5 
days (Park et al., 2007; Utaminingrum, 2011).

Table 2. Type of milk and the amount of milk given per day

\begin{tabular}{lc}
\hline \multicolumn{1}{c}{ Type of milk } & The amount of milk/water \\
\hline Low-fat milk & $0.664 \mathrm{~g} / 4 \mathrm{~mL}$ \\
Standard milk & $0.640 \mathrm{~g} / 4 \mathrm{~mL}$ \\
High-fat milk & $0.638 \mathrm{~g} / 4 \mathrm{~mL}$ \\
\hline
\end{tabular}

\subsubsection{Calcium analysis and its absorption}

Calcium analysis was performed on rats feed, water, milk, feces and urine samples. Calcium analysis includes destruction preparation of solid samples, urine analyte and calcium content analysis.

The preparation of sample destruction was based on a method used by Moreno-Torrese et al. (2000), Zafar et al. (2003), Ayed and Thannoun (2006) and Petrovich et al. (2007). On solid samples such as feed, milk and feces, drying and ashing at $550^{\circ} \mathrm{C}$ were done until samples become white ash. Ash samples were added with several drops of concentrated $\mathrm{HCl}$. Dilution was done using $50 \mathrm{~mL}$ volumetric flask, followed by filtration using Whatman no. 42 filter paper. The filtrate was then stored in a sample bottle.

Urine analysis preparation was based on a method used by Yoshida (2011). Urine samples were diluted by adding $0.2 \mathrm{~mL}$ of $0.1 \mathrm{M} \mathrm{HNO}_{3}$. The solution was then kept overnight. After that, the solution was added with aquadest until the volume reached $1.5 \mathrm{~mL}$.

Quantitative analysis of calcium was performed using AAS at Faculty of MIPA, Gadjah Mada University, based on a method used by Vogel (1990), Silvia (2010), Ayed and Thannoun (2006). Before the samples were analyzed using AAS, a standard curve was prepared using calcium standard with wavelength of $422.7 \mathrm{~nm}$.

The concentration of sample was calculated based on its absorbance value using standard curve equation. The calcium content from concentration result can be calculated using formula:

$$
\text { Calcium content }(\%)=\frac{\mathrm{C} \times \mathrm{V}}{\mathrm{BS} \times 10^{6}} \times \frac{1000 \mathrm{mg}}{1 \mathrm{~g}}
$$

Where $\mathrm{C}=$ concentration (ppm); $\mathrm{V}=$ volume of sample solution $(50 \mathrm{~mL})$; and $\mathrm{BS}=$ weight of sample $(\mathrm{g})$.

Calcium absorption was calculated using formula:

$$
\text { Calcium absorption }(\%)=\frac{\text { Calcium intake }- \text { removed calcium }}{\text { Calcium intake }} \times 100
$$

The amount of calcium intake is the amount of calcium that is consumed from the standard feed, milk treatments and water. The removed calcium is the amount of calcium that is excreted together with feces and urine.

\subsubsection{Data analysis and Interpretation}

The research data were analyzed using SPSS version 16 , which includes data homogenity test, analysis of variance (ANOVA) and Duncan post hoc test.

\section{Results and discussion}

\subsection{Characteristic of milk, feed and drinking water}

At the beginning of this research, proximate analyses and total calcium content analysis were performed on ingredients that would be fed to the rats during the research, i.e. milk powder, standard feed and drinking water. The results are shown in Table 3.

Table 3 shows that fat content on milk powder used was in accordance with Miller et al. (2007) and Belitz et al. (2009), i.e. low-fat milk contains less than $1 \%$ fat, standard milk contains fat content of $4-13 \%$ and high-fat milk contains more than $14 \%$ fat. Moreover, the fat content of the standard feed was $6.02 \%$, also in accordance with fat content in Table 1.

Table 3 also shows the presence of calcium in milk, standard feed and drinking water. The amount of calcium from each ingredient was used to calculate the amount of calcium intake by rats on the day of sampling. The amount of feed consumed was based on Hardiningsih and Nurhidayat (2006) who stated that a healthy rat would consume feed at about $5 \%$ from its body weight. Thus, calcium absorption on rats is not influenced by rats' health condition.

\subsection{The effect of the fat content of milk powder on calcium absorption}

The amount of calcium absorbed was calculated from the amount of calcium intake (from feed, milk powder and drinking water) and the amount of calcium that is removed through feces and urine. ANOVA result showed that the day of sampling and interaction between the day of sampling and types of milk did not give any significant effect $(p>0.05)$. However, types of milk gave a significant effect on calcium absorption $(p<0.05)$. Results of post hoc test using Duncan can be observed in Figure 1 and Figure 2.

Calcium absorption that was not significantly different during 5 days of observation (Figure 1) indicates that on week 3 , the calcium absorption process was stable enough to obtain the absorption data. Calcium absorption level from milk, on average, reached $98.59 \pm 0.22 \%$ and can be categorized as high absorption level. High absorption level might due to the age of rats that were still on the growth period. It is supported by Nixon and Aidong (2011), who reported that during the growth period, high calcium level is required, therefore it 
Table 3. Proximate composition, total calcium content of feed, milk powder, drinking water, and amount of feed consumed by rats

\begin{tabular}{lccccc}
\hline Component & Standard feed & $\begin{array}{c}\text { Low-fat milk } \\
\text { powder }\end{array}$ & $\begin{array}{c}\text { Standard milk High-fat milk } \\
\text { powder }\end{array}$ & $\begin{array}{c}\text { Dowder } \\
\text { powinking water }\end{array}$ \\
\hline Water (\%) & $12.29 \pm 1.36$ & $4.40 \pm 0.28$ & $4.80 \pm 0.014$ & $4.90 \pm 0.00$ & - \\
Ash (\%) & $3.99 \pm 0.48$ & $9.06 \pm 0.01$ & $9.33 \pm 0.01$ & $7.64 \pm 0.26$ & - \\
Protein (\%) & $19.38 \pm 0.46$ & $30.06 \pm 0.54$ & $26.36 \pm 0.64$ & $21.16 \pm 0.11$ & - \\
Fat (\%) & $6.02 \pm 0.02$ & $0.50 \pm 0.00$ & $8.00 \pm 0.26$ & $26.82 \pm 0.71$ & - \\
Carbohydrate (\%) & $59.64 \pm 2.62$ & $55.97 \pm 0.27$ & $51.50 \pm 0.77$ & $39.49 \pm 0.56$ & - \\
Total calcium (mg/g) & $27.60 \pm 1.40$ & $32.80 \pm 1.50$ & $31.97 \pm 1,60$ & $36.40 \pm 1.82$ & $0.04 \pm 0.002$ \\
Amount of feed consumed/day/100 g body weight & $4.20 \pm 0.20$ & $4.72 \pm 0,47$ & $4.45 \pm 0.51$ & $4.84 \pm 0.49$ & - \\
\hline
\end{tabular}

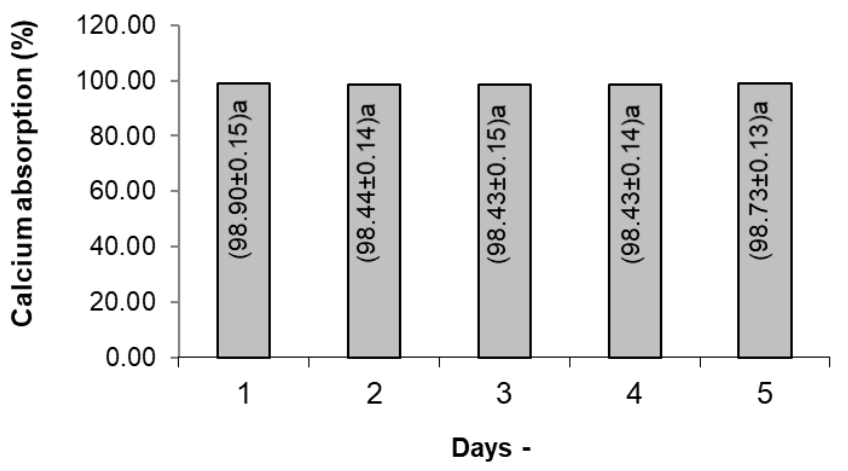

Figure 1. Calcium absorption from milk in the third week. Different superscript letter between bars indicate significant difference at $\alpha=0.05$

would influence the calcium absorption. Thus, Black et al. (2002) mentioned that if children during their growth period do not consume milk, it will retard the growth of body, in terms of height, and disruption in bone's health.

Figure 2 shows that calcium absorption in control rats (which was not fed with any milk) was significantly lower compared to rats that were fed with milk $(\mathrm{p}<0,05)$. Higher calcium absorption due to milk consumption indicates that milk consumption could give positive effect or could increase the calcium absorption. This is due to: 1) protein and fat content in milk, which Muchtadi et al. (1993) and Almatsier (2004) mentioned that calcium absorption is influenced by protein and fat content; and 2) calcium form in milk is organic calcium, as mentioned by McSweeney and Fox (2009) and Brown (2011), which organic calcium is more easily absorbed compared to inorganic calcium (Bhanderi et al., 2010).

Figure 2 also shows that fat content in milk did not significantly affect the calcium absorption level ( $>0.05$ ), which reached $98.67 \pm 0.50 \%$. This means calcium absorption from milk is still high despite the high, medium or low-fat content of milk. High calcium absorption might be related to rats' growth period which requires high calcium and energy because the rats used in this experiment were only 10 weeks old when sampling was performed, and calcium absorption data were collected. Smith and Mangkoewidjojo (1987), Malole and Pramono (1989) mentioned that puberty

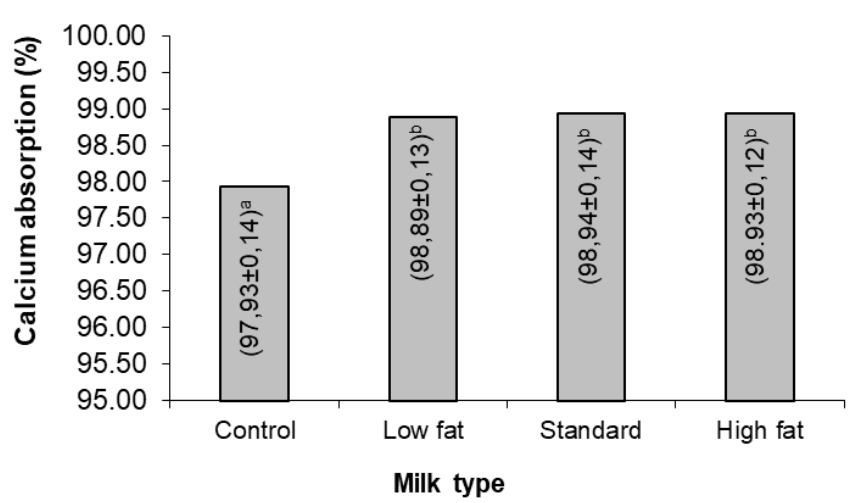

Figure 2. Calcium absorption based on types of milk. Different superscript letter between bars indicate significant difference at $\alpha=0.05$

period of rats was 6-8 weeks, rats will become mature and ready to be inseminated when they are three months old (12-13 weeks).

Although low-fat milk, high-fat milk and standard milk have calcium absorption that was not significantly different, they can give different effects on health. The research conducted by Holmberg and Thelin (2013) and Kratz et al. (2013) showed that dairy products with highfat content contribute to bad effects on health because they can cause obesity and coronary disease. Dairy products contain saturated fatty acids, such as palmitic acid, stearic acid and trans-fat that can cause an increase of fat content in blood when consumed excessively. Based on their effects on health, low-fat milk contains lower saturated fats. Therefore, it can be a healthier choice compared to high-fat milk (Benatar and Ralph, 2014).

\section{Conclusion}

Milk consumption could increase the absorption of calcium carbonate and calcium phosphate mixture of foods. The increase of fat content from low-fat content to high-fat content did not increase the calcium carbonate and calcium phosphate mixture absorption. Calcium absorption from milk was still high, which was about $98.67 \pm 0.50 \%$. 


\section{Conflict of Interest}

The authors declare no conflict of interest.

\section{Acknowledgments}

The authors would like to thank PT Nutrifood Indonesia for their funding support and collaboration during this research.

\section{References}

Abrams, S.A., Griffin, I.J. and Davila, P.M. (2002). Calcium and zinc absorption from lactose-containing and lactose-free infant formulas. The American Journal of Clinical Nutrition, 76(2), 442-446. https:// doi.org/10.1093/ajen/76.2.442

Agnew, J.E. and Holdsworth, C.D. (1971). The effect of fat on calcium absorption from a mixed meal in normal subjects, patients with malabsorptive disease, and patients with a partial gastrectomy. Gut, 12(12), 973-977. https://doi.org/10.1136/gut.12.12.973

Allen, L.H. (1984). Calcium absorption and requirements during the life span. Nutrition News, 47(1), 1-3.

Almatsier, S. (2004). Basic Principles of Nutrition. Jakarta: Gramedia Pustaka.

Alomaim, H., Griffin, P., Swist, E., Plouffe, L.J., Vandeloo, M., Demonty, I., Kumar, A. and Bertinato, J. (2019). Dietary calcium affects body composition and lipid metabolism in rats. PLoS One, 14(1), $\quad 1-21 . \quad$ https://doi.org/10.1371/ journal.pone. 0210760

Ayed, M.A. and Thannoun, A.M. (2006). Calcium bioavailability of calcium carbonate based diet for male growing rats. Mesopotamia Journal of Agriculture, 34(2), 1-17. https://doi.org/10.33899/ magrj.2006.26324

Belitz, H.D., Werner, G. and Pete, R.S. (2009). Food Chemistry. Berlin: Springer.

Benatar, J.R. and Ralph, A.H.S. (2014). The effects of changing dietary intake on trans and saturated fatty acid levels- result from a randomized controlled study. Nutritional Journal, 13, 1-10. https:// doi.org/10.1186/1475-2891-13-32

Bendsen, N.T., Hother, A.L., Jensen, S.K., Lorenzen, J.K. and Astrup, A. (2008). Effect of dairy calcium on fecal fat excretion: a randomized crossover trial. International Journal of Obesity, 32, 1816-1824. https://doi.org/10.1038/ijo.2008.173

Bhanderi, B.M., Pande, A.M. and Panerkar, S. (2010). Influence of organic and inorganic forms of trace minerals supplementation at different doses on daily weight gain and serum mineral levels in male calves. Livestock Research, 22(8), 143-149.
Black, R.E., Williams, S.M., Jones, I.E. and Goulding, A. (2002). Children who avoid drinking cow milk have low dietary calcium intakes and poor bone health. The American Journal of Clinical Nutrition, 76(3), 675-680. https://doi.org/10.1093/ ajcn/76.3.675

Brown, A. (2011). Understanding Food. New York: Cengage Learning.

Gacs, G. and Barltrop, D. (1977). Significance of Casoap formation for calcium absorption in the rat. Gut, 18(1), 64-68. https://doi.org/10.1136/ gut.18.1.64

Hardiningsih, R. and Nurhidayat, N. (2006). The effect of consuming the hypercholesterolemia rationed food to the body weight of white rats wistar with administration of lactic acid bacteria. Biodversitas, 7 (2), 127-130. https://doi.org/10.13057/biodiv/ d070207

Hardinsyah, E.D. and Wirna, Z. (2010). Relationship between milk and calcium consumption with bone density and adolescent height. Retrieved on July 20, 2016 from website http://peternakan. litbang.deptan.go.id/fulltekslokakarya/loksp0835.pdf.

Hayes, D. and Rachel, L. (2009). Food and Nutrition: Acid Indigestion to Calcium. New York: Marshall Cavendish.

Hoenderop, J.G.J., Nilius, B. and Bindels, R.J.M. (2005). Calcium Absorption Across Epithelia. Physiological Reviews, 85(1), 373-422. https://doi.org/10.1152/ physrev.00003.2004

Howard, J., Heller, M.D., Laura, G., Greer, B.A., Sharon, D., Haynes, R.N., John, R., Poindexter, B.S., Charles, Y.C. and Pak, M.D. (2013). Pharmacokinetic and pharmacodynamic comparison of two calcium supplements in postmenopausal women. The Journal of Clinical Pharmacology, 40 (11), 1237-1244. https:// doi.org/10.1177/009127000004001108

Holmberg, S. and Thelin, A. (2013). High dairy fat intake related to less central obesity: a male cohort study with 12 years' follow-up. Scandinavian Journal Primary Health Care, 31(2), 89-94. https:// doi.org/10.3109/02813432.2012.757070

Jacobsen, R., Lorenzen, J.K., Toubro, S., KroqMikkelsen, I. and Astrup, A. (2005). Effect of shortterm high dietary calcium intake on 24-h energy expenditure, fat oxidation, and fecal fat excretion. International Journal Obesity, 29, 292-301. https:// doi.org/10.1038/sj.ijo.0802785

Kelly, O., Cusack, S., Jewell, C. and Cashman, K. D. (2003). The effect of polyunsaturated fatty acids, 
including conjugated linoleic acid, on calcium absorption and bone metabolism and composition in young growing rats. British Journal of Nutrition, 90 (4), 743-750. https://doi.org/10.1079/BJN2003951

Kratz, M., Baars, T. and Guyenet, S. (2013). The relationship between high-fat dairy consumption and obesity, cardiovascular and metabolic disease. Europe Journal Nutrition, 52(1), 1-24. https:// doi.org/10.1007/s00394-012-0418-1

Lorenzen, J.K., Nielsen, S., Holst, J.J., Inge Tetens, I., Rehfeld, J.F. and Astrup, A. (2007). Effect of dairy calcium or supplementary calcium intake on postprandial fat metabolism, appetite, and subsequent energy intake. The American Journal of Clinical Nutrition, 85(3), 678-87. https:// doi.org/10.1093/ajen/85.3.678

Lutz, T. and Scharrer, E. (1991). Effect of short-chain fatty acids on calcium absorption by rat colon. Experimental Physiology, 76(4), 615-618. https:// doi.org/10.1113/expphysiol.1991.sp003530

Masri, E. (2011). Effect of giving of calcium, vitamin D and iron on serum calcium levels in white mice (Rattus novergicus Wistar strain. Scientia, 1(1), 2734. https://doi.org/10.36434/scientia.v1i1.13

Malole, M.B.M. and Pramono, C.S.U. (1989). Use of experimental animals in the laboratory. Bogor: Pusat Antar Universitas Bioteknologi-Institut Pertanian Bogor.

McSweeney, P.L.H. and Fox, P.F. (2009). Advanced Dairy Chemistry. Volume 3: Lactose, Water, Salts and Minor Constituents. New York: Springer.

Miller, G.D., Judith, K.J. and Lois, D.M. (2007). Handbook of Dairy Foods and Nutrition. $3^{\text {rd }}$ ed. New York: CRC Press.

Moreno-Torres, R., Miguel, N., Dolores, R., Reyes, A. and Carmen, L. (2000). A mineralization procedure for determining magnesium in milk. LebensmittelWissenschaft and Technologie, 33(5), 397-400. https://doi.org/10.1006/fst1.2000.0664

Muchtadi, D., Nurheni, S.P. and Made, A. (1993). Nutritional Substance Metabolism 1: Sources, Functions and Needs for the Human Body. Jakarta: Sinar Harapan.

Nixon, R.A. and Aidong, Y. (2011). Cytoskeleton of the Nervous System. New York: Springer. https:// doi.org/10.1007/978-1-4419-6787-9

Nugraheni, K. (2012). Effect of olive oil virgin extract on serum lipid profile of white rat (Rattus novergicus) Sprague Dawley strain of hypercholesterolemia. Semarang: Program Studi Ilmu Gizi, Fakultas Kedokteran, Universitas Diponegoro. Retrieved on August 13, 2016 from website

http://eprints.undip.ac.id/ 35948/1/426_Kartika_Nugraheni_G2C007040.pdf.

Park, H.S., Ahn, J. and Kwak, H.S. (2007). Effect of nanocalcium supplemented milk on bone calcium metabolism in ovariectomized rats. Asian-Australia Journal Animal Science, 20(8), 1266-1271. https:// doi.org/10.5713/ajas.2007.1266

Petrovich, M.B., Filho, V.R.A. and Neto, J.A.G. (2007). Direct determination of calcium in milk by Atomic Absorption Spectrometry using Flow-Injection analysis. Electica Qumica, 32(3), 25-30. https:// doi.org/10.1590/S0100-46702007000300004

Shinya, H. (2001). The Miracle of Enzyme. Bandung: Penerbit Qanita.

Silvia. (2010). Determination of calcium levels in cow's milk, packaged cow's milk and starch by atomic absorption spectrophotometry. Medan: Fakultas Farmasi, Universitas Sumatra Utara. Retrieved on July 26, 2016 from website http:// repository.usu.ac.id/bitstream/ 123456789/14466/1/10E00407.pdf. S-1 Thesis.

Smith, J.R. and Mangkoewidjojo, S. (1987). The Care, Breeding and Management of Experimental Animals for Research in the Tropics. Canberra: IDP.

Spungen, J. (2005). Bowes and Church's Food Values of Portions Commonly Used. New York: Lippincott Williams and Wilkins.

Umami, Z., Nurdiana and Nugroho, F.A. (2015). The effect of giving cow milk powder to serum HDL levels in white rats (Rattus norvegicus) Wistar strain type 2 diabetes mellitus model. Jurnal Gizi Pangan, $10(1), 1-8$.

Utaminingrum, F. (2011). Effect of black soybean yogurt (Black Soyghurt) on cholesterol levels in dyslipidemia rats. Semarang: Program Studi Ilmu Gizi, Fakultas Kedokteran, Universitas Diponegoro. Research Article. Retrieved on July 26, 2016 from website http:// eprints.undip.ac.id/35870/1/408Febriani_Utaminingr um_G2C007030.pdf.

Utama, S. (2011). Determination of calcium levels of goat's milk, wild horse milk and cow's milk by atomic absorption spectrophotometry method. Medan: Fakultas Farmasi, Universitas Sumatra Utara. Retrieved on July 19, 2016 from website http://repository.usu.ac.id/handle/123456789/28515. S-1 Thesis.

Widodo, I.N.T.K. and Edy, W. (2006). The effect of giving a high calcium diet to weight loss in the wistar strain Rattus novergicus. Jurnal Kedokteran Brawijaya, 22, 58-63. https://doi.org/10.21776/ ub.jkb.2006.022.02.2 
Vogel. (1990). Textbook of Qualitative Macro and Semimicro Inorganic Analysis Part I. $5^{\text {th }}$ ed. Jakarta: Kalman Media Pustaka.

Yoshida, M. (2012). Correlation between mineral intake and urinary excretion in free-living Japanese young women. Food and Nutrition Sciences, 3, 123-128. https://doi.org/10.4236/fns.2012.31018

Zafar, T.A., Weaver, C.M., Zhao, Martin, B.R. and Wastney, M.E. (2003). Nondigestible oligosaccharides increase calcium absorption and suppress bone resorption in ovariectomized rats. Journal of Nutrition, 134(2), 399-402. https:// doi.org/10.1093/jn/134.2.399 